\title{
Pemberdayaan Masyarakat Desa Panti dan Suci melalui Kegiatan Budidaya dan Agribisnis Jamur Tiram dengan Pola Kemitraan untuk Memanfaatkan Waktu Luang
}

\author{
Distiana Wulanjari, Setiyono, Sigit Prastowo \\ Fakultas Pertanian Universitas Jember \\ deztyqohhar18@gmail.com
}

\begin{abstract}
Abstrak
Lokasi Kecamatan Panti yang terletak pada ketinggian antara 180-700 mdpl sangat potensial untuk ditanami tanaman perkebunan seperti kopi. Hal ini berdampak pada mata pencaharian warga sekitar yang bekerja paruh waktu di perkebunan, selain bertani di lahan keluarga. Waktu luang yang cukup leluasa dapat digunakan untuk memberdayakan masyarakat mendapatkan penghasilan tambahan melalui kegiatan budidaya dan agribisnis jamur tiram (mengingat lokasi di kedua desa sangat berpotensi untuk mengembangkan budidaya jamur tiram). Di Desa Panti dan Desa Suci terdapat kelompok jamur tiram yang kurang produktif, sehingga dapat dijadikan mitra untuk membudidayakan jamur tiram di sela-sela waktu luang. Harapannya mitra dapat mandiri membudidayakan jamur tiram sehingga dapat meningkatkan perekonomiannya. Oleh karena itu beberapa bentuk kegiatan dilakukan mulai dari teknik pembuatan baglog jamur, teknik budidaya jamur tiram, pemasaran dan analisis kelayakan usaha budidaya jamur tiram. Metode yang digunakan adalah demonstrasi, pelatihan, dan penyuluhan sehingga masyarakat sasaran dapat memahami, melihat dan mempraktikkan kegiatan yang disosialisasikan. Untuk meningkatkan nilai tambah produk jamur tiram maka dilakukan pula sosialisasi mengenai produk olahan berbasis jamur tiram dengan sasaran ibuibu dan pemudi di kedua desa. Produk yang paling diminati warga untuk dikembangkan adalah nugget jamur tiram. Keseluruhan kegiatan tersebut dilakukan pendampingan hingga mitra dapat mandiri. Hasil pengabdian ini mampu menciptakan 10 titik wirausaha yang terdiri dari 4 titik mitra budidaya jamur tiram dan 1 titik mitra olahan jamur tiram di Desa Panti, serta 3 titik mitra budidaya jamur tiram dan 2 titik mitra olahan jamur tiram.
\end{abstract}

Kata Kunci: Pemberdayaan, Jamur tiram, Kemitraan

\begin{abstract}
Panti distric location which is located at an altitude 180-700 masl is very potential to be planted with plantation such as coffee. This has an impact on the livelihoods of local residents who work part time on plantation, in addition as a farmer. The spare time available can be used to empower the community to get the additional income through oyster mushroom cultivation and agribusiness activity (it is considering to the location in both village has the potential to develop oyster mushroom cultivation). In Panti village and Suci village there are groups of oyster mushroom that are less productive, so they can be used as partner to cultivate oyster mushroom on the sidelines of spare time. It is hope hoped that the partners can independently cultivate oyster mushrooms to increase their economy level. Therefore, several activities were carried out start from the technique of making baglog mushrooms, oyster mushroom cultivation technique, marketing and feasibility analysis of oyster mushroom cultivation business. The method that used is demonstration, workshop, and counseling so that the target community can understand, see and practice the socialized activities. To increase the added value of oyster mushroom product, it did socialization of oyster mushroom based processed products is also carried out with the target of mothers and woman in both village. The most popular product as preference to develop is the oyster mushroom nugget. All of this activities are accompanied by assistance until the partner become independent. The result of this activity were able to create 10 enterpreneur consisting of 4 enterpreneur of oyster mushroom
\end{abstract}


cultivation and 1 enterpreneur of oyster mushroom processing in Panti village, and 3 enterpreneur of oyster mushroom cultivation and 2 enterpreneur of oyster mushroom processing in Suci village.

Keywords: empowerment, oyster mushroom, partnership

\section{PENDAHULUAN}

\section{A. Analisis Situasi}

Kecamatan Panti memiliki luas wilayah 9.396 Ha terletak di lereng pegunungan dengan ketinggian 180-700 mdpl. 2096 Ha dari total luas lahan di Kecamatan Panti digunakan sebagai lahan perkebunan (BPS Kabupaten Jember, 2016). Kondisi geografis ini banyak ditumbuhi tanaman perkebunan, menyebabkan suasana udara di daerah ini menjadi sangat sejuk dan dingin (Susilowati dan Raharjo, 2010). Posisi ini menyebabkan masyarakat desa sekitar berprofesi sebagai pekerja kebun (buruh paruh waktu), petani di ladang keluarga, peternak, dan pengrajin aluminium, sehingga masih banyak tersisa waktu luang yang kurang produktif. Kondisi ini menjadi salah satu penyebab kurang sejahteranya kehidupan masyarakat di Kecamatan Panti mencapai 27,6\%(BPS Kabupaten Jember, 2016).

Posisi Kecamatan Panti yang terletak di lereng gunung menyebabkan sedikitnya lahan yang menghambat aktifitas bertani dan bercocok tanam lainnya untuk mendapatkan penghasilan yang layak. Terbatasnya sumber daya alam ini sangat berpotensi mengakibatkan perilaku menyimpang seperti penebangan liar kayu hutan yang dapat menyebabkan banjir dan erosi seperti yang terjadi pada tahun 2016 (Tempo.co Nasional 2016). Agar aktifitas yang dapat menyebabkan kerusakan lingkungan tidak terjadi, maka pemberdayaan masyarakat perlu dilakukan. Hasil pengamatan di lapang (Desa Panti dan Suci) terdapat beberapa usaha penggergajian kayu. Limbah dari usaha ini berupa serbuk gergaji yang belum termanfaatkan dan cenderung menyebabkan polusi udara dalam kondisi kering. Melimpahnya serbuk gergaji yang belum termanfaatkan ini sangat berpeluang untuk diolah menjadi media tanam jamur tiram (log jamur). Selain itu kondisi udara di Desa Panti dan Suci ini sangat mendukung pertumbuhan jamur tiram dan waktu luang yang dimiliki masyarakat juga sangat berpotensi untuk meningkatkan pendapatan.

Program pemberdayaan masyarakat melalui budidaya dan kegiatan agribisnis jamur tiram diharapkan dapat menjadi salah satu solusi bagi masyarakat untuk memperoleh tambahan penghasilan dan meningkatkan kesejahteraan. Dengan memanfaatkan berbagai bahan yang mudah ditemui di sekitar desa, diharapkan masyarakat dapat menjadi wirausaha mandiri dalam pembuatan baglog, budidaya jamur tiram, dan pengolahan produk berbasis jamur tiram.

\section{B. Permasalahan Mitra}

Masyarakat Di Desa Panti dan Suci pernah membudidayakan jamur tiram namun belum menghasilkan produksi yang optimal, sehingga program budidaya jamur tiram menjadi gulung tikar. Warga Desa Panti dan Desa Suci belum mengetahui cara membuat baglog 
dengan memanfaatkan bahan limbah serbuk gergaji yang cukup melimpah di kedua desa, sehingga timbul asumsi bahwa untuk membuka usaha budidaya jamur tiram dan operasional baglog (setiap 4 bulan sekali harus memesan baglog baru) menjadi investasi yang cukup mahal dengan hasil yang belum menjanjikan bagi masyarakat.

Berbagai permasalahan lainnya seperti tingginya kontaminasi Neurospora (jamur oncom/yellow spot) dan Trichoderma spp (jamur hijau/green spot) saat budidaya, masa simpan jamur yang masih rendah (hanya 1-2 hari setelah panen), dan harga jamur tiram segar di tingkat petani yang masih rendah juga menjadi alasan tidak berkembangnya usaha budidaya jamur tiram ini. Hal ini diakibatkan karena keterbatasan pengetahuan petani jamur untuk mengelola kumbung budidaya jamur tiram, misalnya membiarkan tubuh buah jamur terlalu lebar dengan alasan untuk mendapatkan berat yang maksimal, namun yang terjadi jamur tiram menjadi lebih cepat menguning dan layu.

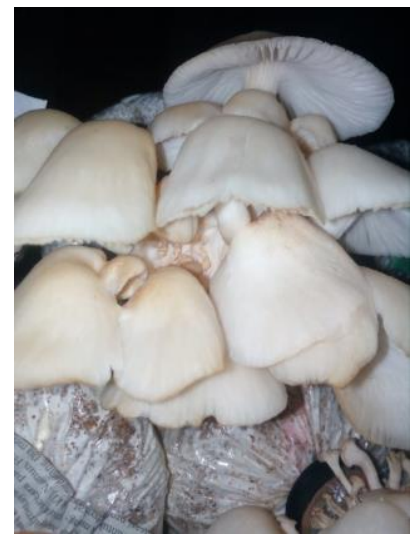

Gambar 1. Kondisi jamur yang pernah dibudidayakan masyarakat

\section{SOLUSI DAN TARGET LUARAN}

Kegiatan ini bertujuan untuk memberdayakan masyarakat Desa Panti dan Desa Suci untuk meningkatkan penghasilan melalui pemanfaatan limbah serbuk gergaji kayu menjadi baglog jamur tiram. Teknologi fermentasi digunakan untuk menghasilkan baglog yang optimal. Beberapa permasalahan yang dihadapi mitra ditawarkan solusinya sebagaimana pada tabel berikut.

Tabel 1. Permasalahan, dan solusi yang ditawarkan

\begin{tabular}{|c|c|c|c|}
\hline No & Permasalahan mitra & Solusi & Target luaran \\
\hline 1 & $\begin{array}{l}\text { Belum mengetahui cara } \\
\text { pembuatan baglog dari } \\
\text { limbah serbuk gergaji }\end{array}$ & $\begin{array}{l}\text { Melakukan pelatihan } \\
\text { dan edukasi terkait } \\
\text { pembuatan baglog dan }\end{array}$ & $\begin{array}{l}\text { Masyarakat dapat } \\
\text { mandiri memproduksi } \\
\text { baglog jamur tiram }\end{array}$ \\
\hline 2 & $\begin{array}{l}\text { Produktivitas dan masa } \\
\text { simpan jamur kurang } \\
\text { optimal }\end{array}$ & $\begin{array}{l}\text { budidaya jamur tiram } \\
\text { untuk meningkatkan } \\
\text { pengetahuan petani }\end{array}$ & $\begin{array}{l}\text { Masyarakat memahami } \\
\text { teknis budidaya dan } \\
\text { masa panen yang tepat } \\
\text { untuk menghasilkan } \\
\text { masa simpan jamur } \\
\text { tiram yang optimal }\end{array}$ \\
\hline
\end{tabular}




\begin{tabular}{|c|c|c|c|}
\hline 3 & $\begin{array}{l}\text { Harga jamur tiram yang } \\
\text { dihasilkan } \\
\text { kompetitif }\end{array}$ & 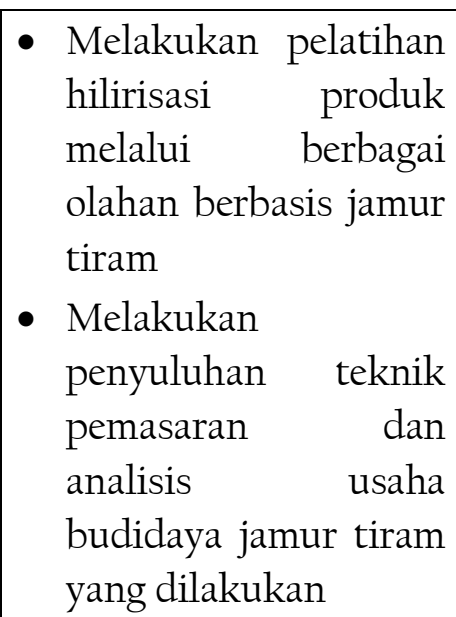 & $\begin{array}{l}\text { - Menghasilkan } \\
\text { beberapa produk } \\
\text { olahan berbasis jamur } \\
\text { tiram } \\
\text { - Mandapatkan pangsa } \\
\text { pasar produk olahan } \\
\text { dan pelaku usaha } \\
\text { memperoleh } \\
\text { keuntungan dari hasil } \\
\text { penjualan }\end{array}$ \\
\hline
\end{tabular}

Kegiatan ini dilakukan dengan cara demonstrasi (praktik langsung) dan penyuluhan dengan tujuan memberikan edukasi budidaya jamur tiram berikut berbagai olahannya untuk meningkatkan nilai jual produk. Berbagai kegiatan dilakukan seperti pelatihan pembuatan baglog dan budidaya jamur tiram untuk meningkatkan skill dan pengetahuan masyarakat, pelatihan produksi berbagai olahan berbasis jamur tiram untuk meningkatkan hilirisasi produk dan meningkatkan wirausaha masyarakat, dan melakukan penyuluhan teknik pemasaran serta analisis usaha yang dikembangkan. Pasca kegiatan dilakukan pendampingan wirausaha sehingga masyarakat menjadi wirausaha/mitra mandiri. Target kegiatan ini terciptanya beberapa wirausaha mandiri (wirausaha budidaya dan produk olahan) di bidang jamur tiram. Diharapkan melalui terbentuknya titik usaha baru di Desa Panti dan Desa Suci dapat berkontribusi untuk meningkatkan pendapatan mitra dan dapat menjadi produk unggulan desa.

\section{METODE PELAKSANAAN}

Pemberdayaan masyarakat ini dilakukan di dua desa di Kecamatan Panti, yaitu Desa Panti dan Desa Suci yang terdapat usaha penggergajian kayu. Sasaran program pemberdayaan beragam, diantaranya Karang Taruna Dusun Darungan, kelompok tani Taruna Tani, kelompok ibu-ibu pengajian dan rumah tangga non penghasilan. Kegiatan ini dilakukan bersama program KKN mahasiswa. Teknis pelaksanaan kegiatan adalah sebagai berikut.

\section{A. Membuat Percontohan/Demonstrasi Budidaya Jamur Tiram}

Tahapan kegiatan ini adalah bermitra dengan salah satu masyarakat yang bersedia menyediakan tempat untuk dijadikan kumbung budidaya. Selanjutnya menyediakan baglog starter yang siap produksi. Kegiatan ini bertujuan sebagai daya tarik minat masyarakat dan mengedukasi cara membudidayakan jamur tiram. 


\section{B. Workshop/Pelatihan Pembuatan Baglog}

Kegiatan ini sebagai tindak lanjut untuk meningkatkan kemampuan masyarakat sasaran (karang taruna Dusun Darungan dan kelompok tani Taruna Tani) dalam memanfaatkan limbah serbuk gergaji menjadi baglog jamur tiram. Tujuan kegiatan ini sasaran dapat mandiri dalam mengolah limbah dan mampu memproduksi baglog jamur tiram.

\section{Membuat Percontohan Untuk Sampling Berbagai Olahan Berbasis Jamur Tiram}

Sebelum dilakukan pelatihan pembuatan berbagai olahan berbahan baku jamur tiram, maka dilakukan sampling terlebih dahulu dengan membuat tester. Berbagai olahan seperti nugget jamur, kerupuk jamur, bakso jamur, dan sate jamur dicobakan untuk mengetahui preferensi masyarakat. Sasaran kegiatan ini tidak hanya kelompok ibu-ibu pengajian, namun juga melibatkan karang taruna dan kelompok tani pembudidaya jamur tiram. Tujuan lain dari kegiatan ini adalah untuk meningkatkan pengetahuan sasaran bahwa jamur tiram dapat dijadikan berbagai olahan yang menarik dan layak jual.

\section{Workshop/Pelatihan Pembuatan Berbagai Olahan Berbasis Jamur Tiram}

Hasil dari sampling menunjukkan bahwa sebagian besar masyarakat sasaran memilih nugget dan kerupuk jamur tiram sebagai produk olahannya. Sebagai tindak lanjut dilakukan workshop pembuatan nugget dan kerupuk jamur tiram berikut analisis usahanya. Sasaran kegiatan ini adalah pemberdayaan kelompok ibu-ibu pengajian.

\section{E. Lokakarya}

Kegiatan ini dilakukan untuk mendapatkan umpan balik/masukan dari seluruh kegiatan yang telah dilakukan. Kegiatan dihadiri oleh seluruh pemangku kepentingan, seperti perangkat desa, mitra, dan pengabdi.

\section{HASIL DAN P EMBAHASAN}

Berbagai kegiatan pelatihan dilakukan untuk meningkatkan pengetahuan dan keterampilan mitra seperti workshop budidaya jamur tiram, workshop pembuatan aneka olahan berbasis jamur tiram, dan workshop analisis usaha jamur tiram. Masyarakat sangat antusias mengikuti berbagai kegiatan hingga dapat mandiri dalam menjalankan usahanya, berikut didampingi tim pengabdi dan mahasiswa KKN-PPM.

\section{A. Workshop Budidaya Jamur Tiram}

Kegiatan workshop dihadiri oleh 15 orang di masing-masing desa yang terdiri dari pemuda karang taruna, kelompok tani, dan warga sekitar yang tertarik mengikuti pelatihan. Kegiatan dilakukan mulai dari pelatihan pembuatan baglog. Penyiapan bahan baku seperti serbuk gergaji yang telah diayak, pupuk TSP, kapur, gips, dedak, bekatul dan bahan lainnya dilakukan oleh mitra dan didampingi pengabdi. Bahan- 
bahan tersebut selanjutnya dicampur menjadi satu dengan komposisi tertentu, ditambahkan air dan dihomogenkan menggunakan cangkul. Media selanjutnya difermentasikan selama 15 jam. Setelah 15 jam media siap dikemas kedalam plastik PP untuk dilakukan sterilisasi media.

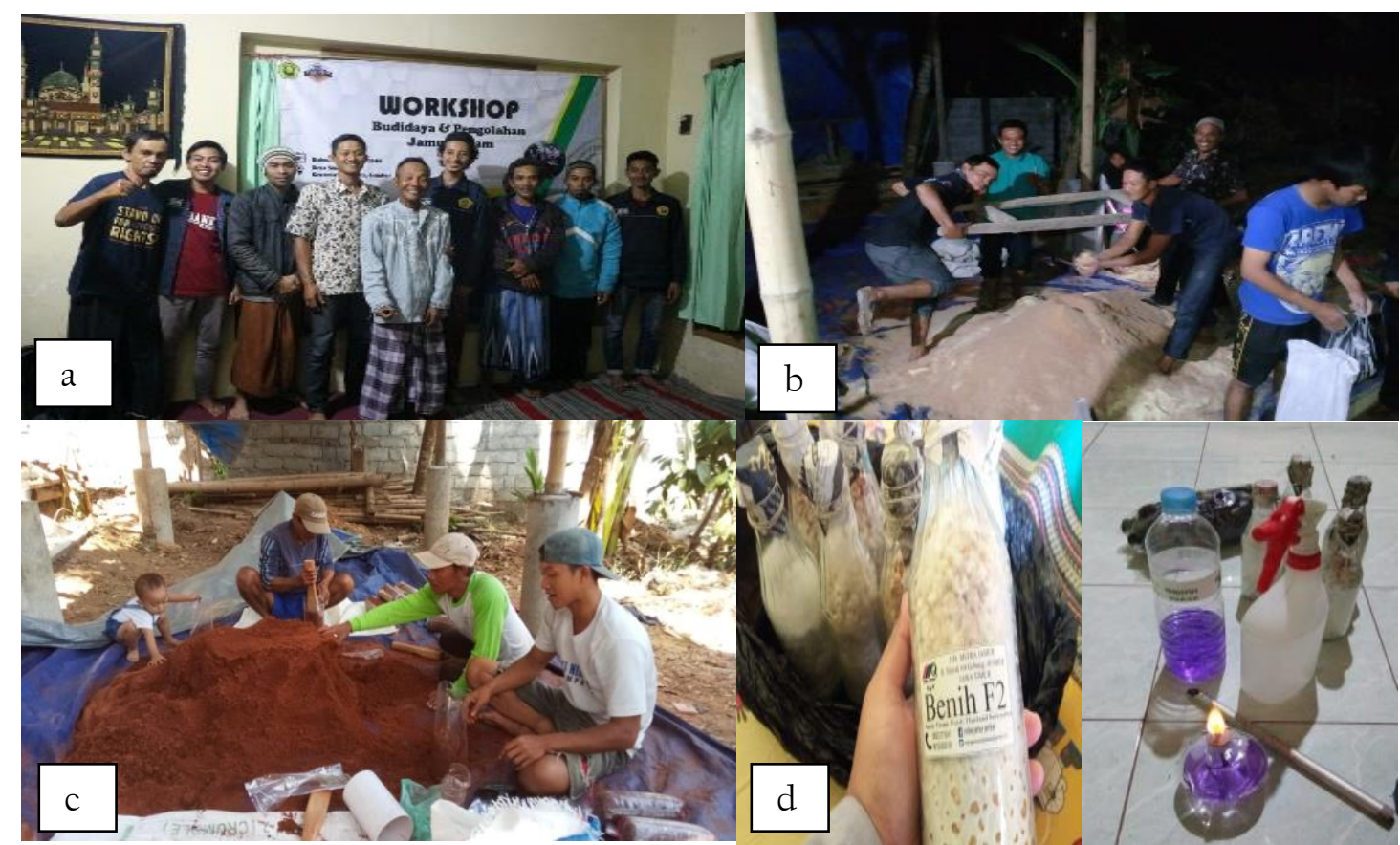

Gambar 2. (a) pelaksanaan workshop budidaya jamur tiram, (b) Persiapan bahan untuk pelatihan, (c) Pembuatan baglog bersama warga, (d) Bahan dan alat inokulasi baglog

Selama 45 hari efektif melakukan kegiatan pendampingan petani mitra telah mahir mengolah limbah serbuk gergaji kayu menjadi baglog jamur yang produktif. Dengan memanfaatkan waktu luang yang tersedia, kelompok tani jamur tiram di Desa Panti menghasilkan 3.550 log jamur dan kelompok tani jamur tiram di Desa Suci mencapai 3623 log jamur dengan persentase kontaminasi sebesar 1,4\%. Proses pembuatan baglog yang mudah menjadi ketertarikan tersendiri bagi kelompok pemuda lain maupun perseorangan disekitar tempat pendampingan, sehingga di masing-masing desa menghasilkan antara 3-4 kumbung produksi jamur. Hingga akhir masa pengabdian telah terbentuk 7 kumbung produktif berkapasitas 1000 baglog dengan rincian 4 kumbung di Desa Panti dan 3 kumbung di Desa Suci.

Satu resep pembuatan baglog dapat menghasilkan minimal 125 baglog dengan total harga produksi Rp 205.000,00. Diasumsikan satu baglog mampu menghasilkan produksi minimal 0,5 kg maka produksi jamur tiram segar yang bisa dihasilkan mencapai $62,5 \mathrm{~kg}$. Harga jual jamur tiram di pasaran saat ini mencapai Rp 20.000,00 sedangkan petani jamur mampu berkompetisi dengan harga Rp 15.000,00 sehingga dalam sekali produksi (125 baglog) petani menghasilkan total pendapatan kotor Rp 937.500,00. Total pendapatan bersih yang didapatkan oleh petani jamur dalam satu 
resep produksi baglog mencapai $723.500,00 / 4$ bulan atau $\mathrm{Rp} 183.125,00$ perbulannya (rerata siklus hidup baglog 4 bulan yang dapat dipanen sebanyak 7 kali).

\section{B. Workshop pembuatan berbagai olahan berbasis jamur tiram}

Hasil produksi budidaya jamur tiram tidak hanya dipasarkan dalam bentuk segar saja, namun juga dilakukan pengolahan sebagai upaya peningkatan nilai ekonominya. Pembuatan berbagai olahan jamur tiram dilakukan untuk menampung hasil panen pada masing-masing kumbung. Hal ini dilakukan sebagai bentuk antisipasi apabila pangsa pasar jamur tiram kurang terserap. Peningkatan nilai ekonomi jamur tiram melalui berbagai olahan yang ditawarkan kepada masyarakat seperti nugget jamur, sate jamur, bakso jamur, dan kerupuk jamur. Preferensi Desa Panti lebih condong mengembangkan nugget jamur, sedangkan Desa Suci mengembangkan nugget jamur dan kerupuk jamur. Pelatihan ini dihadiri oleh 15 orang di masing-masing desa yang terdiri dari kelompok ibu-ibu pengajian dan pemudi di masing-masing desa.

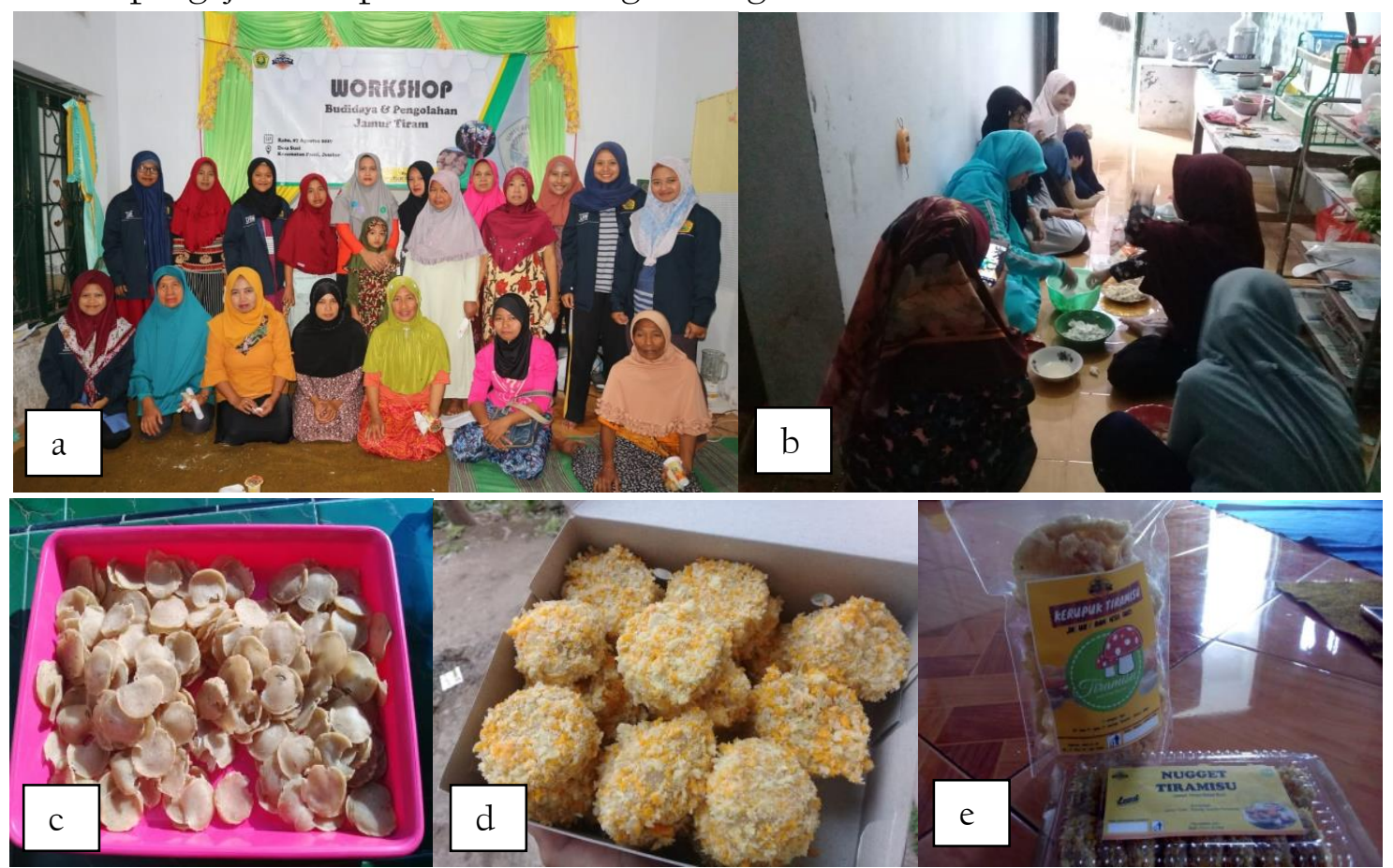

Gambar 3. (a) pelaksanaan workshop olahan berbasis jamur tiram, (b) Pelatihan pembuatan nugget jamur, (c) Produk kerupuk jamur tiram olahan mitra, (d) Produk nugget jamur olahan mitra, (e) Produk nugget jamur dan kerupuk jamur Desa

Suci yang siap jual

Masing-masing desa telah memiliki mitra yang diharapkan dapat menjadi sentra olahan produk berbasis jamur tiram. Pengembangan produk nugget jamur siap makan di Desa Panti oleh 1 mitra telah mencapai 550 potong setiap minggunya dan telah dirasakan manfaatnya dalam hal peningkatan ekonomi keluarga. Modal produksi Rp 125.400,00 per minggunya (menggunakan peralatan yang telah dimiliki mitra), mitra mendapatkan untung sebesar Rp 149.600,00 dengan harga jual Rp 500/potong. Demikian pula dengan produksi kerupuk jamur yang dikembangkan di Desa Suci. Mi- 
tra mampu mengolah kerupuk jamur hingga 3 resep ( 2 hari sekali) dalam satu minggu. Produksi kerupuk jamur lebih condong pada penjualan kerupuk jamur mentah. Mitra mengolah jamur menjadi kerupuk dan mengemas dalam bentuk kemasan standing pouch berisi 200 g dan dijual dengan harga Rp 6.500/kemasan. Dengan modal Rp 67.800,00 mitra dapat menghasilkan 18 kemasan per minggunya dan mendapatkan keuntungan bersih sebesar Rp 49.200,00. Penjualan kerupuk jamur mentah ini lebih dipilih oleh mitra karena proses perputaran modal lebih cepat dan hemat tenaga.

\section{Lokakarya}

Lokakarya dilakukan untuk mendapatkan umpan balik dari seluruh pemangku kepentingan. Loka karya dihadiri sebanya 30 orang di masing-masing desa yang terdiri dari aparat desa, mitra, dan masyarakat. Hasil lokakarya ini berupa masukan untuk pengembangan produk, seperti perbaikan kemasan, harga jual, dan rasa produk. Harapan berbagai pihak melalui kegiatan ini sentra produksi jamur tiram dan pengolahannya dapat membangkitkan jiwa wirausaha masyarakat dan mampu meningkatkan kesejahteraan warganya.

\section{KESIMPULAN DAN SARAN}

Kegiatan pengabdian yang dilakukan bersama mahasiswa KKN-PPM dihasilkan 10 titik wirausaha di Desa Panti dan Desa Suci Kecamatan Panti Kabupaten Jember. 7 sentra usaha budidaya jamur tiram dan 3 sentra usaha olahan berbasis jamur tiram dapat meningkatkan penghasilan tambahan bagi pelaku usaha antara Rp 183.125,00 - Rp 348.300,00 (bergantung jenis usaha yang dikembangkan).

Berbagai upaya untuk menstimulasi produksi diharapkan dapat dilakukan, sehingga dapat disarankan produk yang telah dikembangkan lebih distrandarkan bentuk dan ukurannya dan didaftarkan ijin produksi industri rumah tangga (P-IRT) sebagai jaminan keamanan pangan yang dikeluarkan oleh dinas kesehatan, sehingga kualitas produk lebih terjamin. Pola kemitraan juga dapat dikembangkan lebih lanjut untuk memperluas pemasaran produk olahan berbasis jamur tiram.

\section{E. UCAPAN TERIMA KASIH}

Penulis mengucapkan terima kasih kepada Direktorat Riset dan Pengabdian Masyarakat, Dirjen Penguatan Riset dan Pengembangan, Kementerian Riset, Teknologi, dan Pendidikan Tinggi. Sesuai dengan Penugasan Pelaksanaan Program Pengabdian Masyarakat No: 058/SP2H/PPM/DRPM/2019.

\section{F. DAFTAR PUSTAKA}

BPS Kabupaten Jember. 2016. Kecamatan Panti dalam Angka. Badan Pusat Statistik Kabupaten Jember 
Irnani, M. 2014. Pengaruh Perbandingan Gluten dan Jamur Tiram Putih terhadap Mutu Organoleptik Sosis Vegan. E-journal Boga 3 (1)

Lombo, H. 2015. Konsep Pembangunan Ekonomi Pedesaan dalam Upaya Mensejahterakan Masyarakat dari Pedesaan. http://www.kompasiana.com/lombohelfried/konseppembangunan-ekonomipedesaan 55547a0bb67e616914ba54ad. Diakses pada 19 Juni 2018

Susilowati dan B. Rahardjo. 2010. Petunjuk Teknis Budidaya Jamur Tiram (Pleourotus ostreatus var florida) yang Ramah Lingkungan (Materi Pelatihan Agribisnis bagi KMPH). Merang REDD Plot Project. Palembang

Tempo. Co Nasional. 2006. Banjir Bandang di Jember Tewaskan 51 Orang. https://nasional.tempo.co/read/news/2006/01/03/05571684/banjir-bandangdi-jember-tewaskan-51-orang. Diakses pada 11 Juli 2018

Witanto, B., F.S. Pranata, dan L.M.E. Purwijatiningsih. 2013. Pembuatan Sosis Jamur Tiram Putih (Pleurotus ostreatus Jacq.) dan Tepung Rebung dengan Kombinasi Tepung Tapioka dan Karaginan (Eucheuma cottonii Doty). Jurnal Ilmiah Biologi. pp 1-3 